\title{
Early Identification and Intervention on Language Deficits and Behavioral Difficulties in Early Childhood Education
}

\author{
Cristina de Andrade Varanda ${ }^{1,2, *}$ (D), Eva Cristina de Carvalho Souza Mendes ${ }^{2}$, \\ Maria da Graça Giordano de Marcos Crescenti ${ }^{2}$, Rita de Cássia Gottardi van Opstal Nascimento ${ }^{3}$, \\ Karla Regina de Jesus Grillo ${ }^{3}$, \& Fernanda Dreux Miranda Fernandes ${ }^{1}$ (D) \\ ${ }^{1}$ Universidade de São Paulo, São Paulo, SP, Brasil \\ ${ }^{2}$ Universidade Paulista, São Paulo, SP, Brasil \\ ${ }^{3}$ Prefeitura Municipal de Santos, Santos, SP, Brasil
}

\begin{abstract}
This project had the aim of detecting and intervening in difficulties of language and behavior in children at the age of three and four. A hundred seventy-eight children were assessed in behavior, expressive and receptive vocabulary and in central auditory processing. 84 children constituted the experimental group and were engaged in an intervention for the development and refinement of language and management of behavior problems through activities developed in software used in tablets, concrete games and orientation provided to their parents and teachers by a professional team composed by speech therapists, psychologists and psycho pedagogues. Posttest analysis indicated significant difference between the vocabulary and language scores, suggesting that this model of early assessment and intervention can be a successful strategy in school environments.
\end{abstract}

KEYWORDS: child development, language development, child behavior, evaluation of results of preventive actions, early intervention

\section{Identificação Precoce e Intervenção em Déficits de Linguagem e Dificuldades Comportamentais na Educação Infantil}

\begin{abstract}
RESUMO - Esta pesquisa objetivou detectar e intervir nas dificuldades de linguagem e comportamento em crianças de três e quatro anos de idade. Foram avaliadas 178 crianças nas áreas de comportamento, vocabulário expressivo e receptivo e processamento auditivo central. O grupo experimental, com 84 crianças, foi submetido à intervenção para o desenvolvimento e aprimoramento de linguagem e manejo de comportamentos-problema, por meio de atividades desenvolvidas em aplicativos usados em tablets, jogos concretos e orientações fornecidas a seus pais e professores por uma equipe de fonoaudiólogos, psicólogos e psicopedagogos. As análises do pós-teste indicaram diferença significativa entre os resultados dos testes de vocabulário e comportamento, sugerindo que esse modelo de avaliação e intervenção precoce pode ser uma estratégia bem-sucedida em ambiente escolar.
\end{abstract}

PALAVRAS-CHAVE: desenvolvimento infantil, desenvolvimento da linguagem, comportamento infantil, avaliação de resultado de ações preventivas, intervenção precoce

The good development of language and of an adaptive behavioral repertoire stands for two important milestones in child development that could enable the proper psychosocial and cognitive development. Thus, the possibility of early detection and intervention in difficulties of language and behavior, in order to flag and prevent potential problems in the acquisition of academic and social skills, becomes essential.

The development of behavior problems in early childhood has been related, on one hand, to adolescent delinquency (Timmermans, van Lier, \& Koot, 2009) and on the other hand to later difficulties in academic performance (D'Abreu

*Email: crisvaranda@usp.br

- Submetido: 27/12/2016; Revisado: 11/03/2018; Aceito: 10/08/2018. 
\& Marturano, 2010; Timmermans, van Lier, \& Koot, 2009). Both juvenile delinquency and problems of academic performance during school years are related to externalizing behavior problems (Arnold, 1997; D'Abreu \& Marturano, 2010; Timmermanset al., 2009). Child behavior problems may interfere on the external environment and are called externalizing problems, or may not directly interfere with the environment and are called internalizing ones. Internalizing behaviors are exemplified as withdrawal, somatic problems, sadness, fear, depression and anxiety; while externalizing agents have been described as aggressiveness, hyperactivity, disobedience and poor control of impulses (Achenbach \& Rescorla, 2000; Moura, Marinho-Casanova, Meurer, \& Campana, 2008). Externalizing behaviors are the most commonly detected and flagged by parents and teachers due to their significant interference with the environment. In fact, problems of externalizing behavior and academic difficulties have been significant challenges in child clinical psychology (Arnold, 1997).

Likewise, language is a core skill and a pillar to the cognitive and socio-emotional development, essential to fit and work in society (Bornstein, Hahn, \& Suwalsky, 2013). Emotional and behavioral problems may result from language delays that interfere with peer and adult relationships. Similarly, behavioral and emotional problems may interfere with language development (Achenbach \& Rescorla, 2000). In fact, some authors suggest the interdependence of language development and behavioral repertoire (McClelland et al. 2007; Vallotton \& Ayoub, 2010; Varanda et al., 2015a).

McClelland et al. (2007) investigated predictive relationships between behavioral regulation and emerging literacy, vocabulary, and math skills among children from 54 American preschool classrooms. In this survey, behavioral regulation refers to paying attention, following instructions, and inhibiting inappropriate actions. The authors found a correlation between gains in behavioral regulation throughout preschool, directly measured through a task of observation, with greater vocabulary and improved math and literacy skills. Low inhibitory control, which does not allow children to inhibit inappropriate actions, is related to the expression of externalizing behavior problems.

In 1997 Arnold studied the co-occurrence of externalizing behaviors and academic difficulties among at-risk boys. Despite these findings, the topic has not received due attention in surveys about detection and prevention of school difficulties and their social components.

There are some important conditions for a successful language development. One of these concerns the integrity of the central auditory system. Varanda et al. (2015a) investigated auditory processing skills - which are the mechanisms and processes of the auditory system responsible for the expression of sound localization and lateralization, discrimination and recognition of auditory patterns, temporal aspects of hearing and auditory performance with degraded acoustic signals (American Speech-Language-Hearing Association [ASHA], 1996) and internalizing and externalizing behaviors among 187 children with an average age of 3.8 years and their parents. Behaviors, described by parents as: "Behaves very childishly for their age", "Constantly seeks help"; "Doesn't eat well"; "Doesn't feel guilty after misbehaving"; "Easily gets frustrated"; "Has nervous movements or tics"; "Nervous, irritable or tense", "Clumsy with poor motor coordination"; "Repeatedly shakes the body or the head"; "Stares or looks concerned"; "Gets sulky easily" and "Runs away" were correlated with difficulties in auditory processing.

Thus, tests that assess problems in the central auditory processing of children still in day care nursery could benefit future interventions in the kindergarten and preschool, to compensate or minimize those problems, mitigating the damage on the acquisition of reading and writing skills in elementary school. Toscano e Anastasio (2008, p. 2) state that "one of the ways to perform preventive work in school-age children would be to investigate auditory skills such as detection, sound localization and auditory memory in children of 4-6 years old". To that, Capovilla and Salido (2011) propose the Simplified Assessment of Central Auditory Processing.

Vallotton and Ayoub (2011) used data collected longitudinally from 120 children aged 14, 24 and 36 months to assess the impact of expressive vocabulary and speech production on the improvement of self-regulation and to determine the existence of associations between these domains. The results revealed gender differences in self-regulation paths and the impact of language on selfregulation. Vocabulary was better predictor of self-regulation than speech production and both positively predicted children's self-regulation levels. Results also revealed that in early development words are tools that can be applied to the self-regulatory task and may be more necessary for boys than for girls.

Wright and Neuman (2014) investigated how activities to develop vocabulary are approached in preschool activities in 55 schools of different socioeconomic levels in the United States. The authors found that preschool vocabulary teaching consisted of explanations of short words provided by teachers, and that explanations occurred intermittently and in different contexts throughout the day. However, they noted that these words discussed by teachers served to make children understand their surroundings, but tended to be simple words. Evidence suggested that vocabulary taught by teachers in more economically privileged schools was more consistent and included more challenging words than the vocabulary taught in schools with lower socioeconomic status.

In a study conducted in a different educational context, Whorrall and Cabell (2016) report positive results of a program to improve preschool children's oral language 
(Whorrall \& Cabell, 2016) and its impact on reading skills. In this proposal, non-course activities such as meals and recreation were used as opportunities for the development of activities. to expand the vocabulary. The results suggested that children of this age group do not receive specific vocabulary stimulation, despite the relevant body of knowledge that indicates a relationship between this development and future academic performance.

Beyond the possibilities of intervention in school environment, Hancock, Kaiser and Delaney (2002) argue that routine parent-child interactions, language support, and behavior management are closely related. The authors suggest that parents less responsive to their children may not provide a language-rich environment and may have difficulty in managing behavior problems. Therefore, they investigated the effect of a proposed intervention aimed to teach parents of five children strategies for positively responding to their children's behavior in moments of play, both by decreasing negative verbalizations and increasing positive verbalizations. Parents attended 30 sessions lasting 30 to 45 minutes each. The results showed that children had positive changes in language and behavior, although the maintenance and generalization of these effects varied among children.

It is in this context, considering that educational needs in Brazil often require adjustments to fit into challenging contexts that this study in inserted. It is sought to identify feasible possibilities for early identification and intervention that allow young children to better use academic opportunities.

Still in day care nursery school, with 3 years old, children can be assessed regarding their understanding and production of speech, as such assessment is "of vital importance for the early detection of language delays and disorders and early intervention, taking advantage of neural plasticity to maximize efficacy." (Capovilla, Negrão, \& Damázio, 2011, p. 5).
To assess the externalizing behaviors that are correlated with academic performance, according to Duarte and Bordin (2000), the most widely used instrument to identify mental health disorders in children and adolescents, based on parental information, is the Child Behavior Checklist (CBCL). The Brazilian version of the CBCL (4-18 years old) is called "Childhood and Adolescent Behaviors Inventory" and has preliminary validation data (Bordin, Mari, \& Caeiro, 1995). This questionnaire is to be answered by the children's parents, providing information on social competence, depression and isolation, aggressiveness, antisocial behavior and anxiety. This research used the Behavior Inventory in the version for ages $1 \frac{1 / 2}{2}$ to 5 years (Achenbach, \& Rescorla, 2000; Silvares, Rocha, \& Linhares, 2010).

Therefore, both language and behavioral difficulties can be early detected to flag potential problems in the acquisition of academic and social skills. To that, children should be evaluated with 3 years old regarding language and behavior, and reevaluated on the same skills at the age of 4 years, to prevent difficulties arising from such deficits. Therefore, a study aimed at early assessment of children to help teachers and parents to minimize and solve these problems, could ground efficient strategies to meet the needs of childhood care in family and institutionalized environments.

The purpose of this study was to evaluate three-yearold children in early education (maternal II), regarding language (expressive and receptive vocabulary) and central auditory processing skills and behaviors; perform an intervention for the development of language and adaptive behavioral repertoire in a group of children and reevaluate the same children, at the age of four years, in early education (kindergartens) regarding behaviors and central auditory processing, comparing the group submitted to the intervention and the control group.

\section{METHOD}

\section{Participants}

The research engaged 178 children ( 90 girls, 88 boys, with mean age of 3.7 years), students from four schools of the Santos Municipal School Network, divided into two groups: experimental and control. Their parents have also participated in the survey. Using the occupational scale proposed by Hollingshead (2011) and adopting the occupational factor of that scale, almost half of the parents $(47 \%)$ are classified in the $3^{\text {rd }}$ and $4^{\text {th }}$ categories (machine operators, semi-skilled workers, skilled carpenters, electricians, machinists, plumbers), $11 \%$ are classified in the $6^{\text {th }}$ category as technicians, semi-professionals, small business owners, other $11 \%$ are classified in the $1^{\text {st }}$ category as rural workers, manual workers and domestic workers, $9 \%$ of them are classified in the $2^{\text {nd }}$ category as unskilled workers as messengers, waiters, bricklayers, $7 \%$ of them are in the $8^{\text {th }}$ category as managers, mid-sized business owners and administrative officers, $6 \%$ of them are in the $5^{\text {th }}$ category as sales professionals, administrative professionals, $4 \%$ of in the $7^{\text {th }}$ category as small business executives, farm owners, art professionals, managers, and other professionals, and only 2 of them rank in the $9^{\text {th }}$ category as senior executives, big business owners, and graduate professionals. Two percent of the parents are unemployed and $1 \%$ of them did not answer the question about profession. This scale is 
made up of nine categories, where the $9^{\text {th }}$ is the highest, and includes the professions of people of higher socioeconomic compared to the professions of people in the categories below it (Hollingshead, 2011).

\section{Instruments}

Parents of all children were interviewed individually answering the CBCL questions (Achenbach \& Rescorla, 2000; Bordin et al., 1995), for ages of $1 \frac{1}{2}$ to 5 years. The CBCL results encompass two different domains of behavior: internalizing (emotional reactivity, anxiety and depression, somatic complaints and withdrawal) and externalizing (attention problems and aggressive behavior). The behaviors present in a list of 100 specific behavioral situations are rated and scored by parents as "not true" with a score of " 0 ", "somewhat true or sometimes true" with a score of " 1 " and "very true or often true" with score 2. The higher the score, the greater the behavioral problems pointed out by parents. Jointly with the CBCL, parents responded the Language Development Questionnaire (LDS; Rescorla \& Alley, 2001; Silvares et al., 2010), a list of 310 words that parents of the children being assessed should identify as being produced or not by the children.

Children were also assessed in receptive vocabulary using the Usp Auditory Vocabulary Test - TVAud-A33o (Capovilla et al., 2011), which is a test that assesses receptive vocabulary since early stages, from the age of 1 year and 6 months on. In this test, the child listens to a word from a list spoken by the evaluator and, then, must choose from five different figures, one figure that corresponds to the word heard. There are 33 items and hits are summed to provide the raw hit score for the test.

Moreover, children were assessed regarding expressive vocabulary using the Expressive Vocabulary Test - TVExp100r (Capovilla et al., 2011), which is a test that evaluates expressive vocabulary in the early stage. In this test, the evaluator presented a slide containing a figure, and the child being assessed should produce the name of the figure. There are 100 items that are summed up to get the gross score.

Children were also assessed regarding central auditory processing through the Simplified Auditory Processing Assessment (ASPA; Pereira \& Schochat, 1997), as an instrument to detect potential changes in auditory processing. This instrument evaluates memory, auditory discrimination (verbal and nonverbal), spatial orientation related to sound localization and presence or absence of cochlear-eyelid reflex. The ASPA normality criteria for results are: (a) sound localization: hit at least four of the five directions presented, and the lateral localization must be present; (b) nonverbal sequential memory: understand the request and hit at least two sequences of four sounds in three presentations; (c) verbal sequential memory: hit at least two sequences of four syllables in three presentations. In this assessment, the following answers were computed: with respect to the Sound Sequencing subtest, the correct answer to each sequence of instrumental sounds was computed with a value of 1 , with three sequences in total. In addition, one point was computed to the adequate phonoarticulatory production of each syllable (total of three) and to each syllable sequence (total of three). As for the Sound Location subtest, one point was computed to each correct sound localization, totaling five items.

\section{Procedures}

The survey was approved by the Ethics Committee of the Medical School of the University of São Paulo under research protocol No. 381/14. The parents of the students involved in the research signed the Informed Consent Form.

After the behavioral assessment, through the CBCL completed by the parents and in vocabulary through the LDS also completed by them, children of the experimental and control groups were evaluated in language through the Usp Auditory Vocabulary Test - TVAud-A33o. Expressive Vocabulary Test - TVExp-100r and ASPA.

In the intervention stage, 3-year old children from schools in the experimental group were subjected to a program of intervention in small groups of up to five students, for three months, in daily sessions lasting 50 minutes each. The intervention was carried out in the school classrooms, at school time, by a group of educators with degree in Psychology, Speech Therapy, specialization in Psychopedagogy and experience in the use of new information and communication technologies (NTICS), with the assistance of the students' teacher. Still in this same stage, parents and teachers received guidance, in three to four meetings throughout the research, regarding the management of problem behaviors.

Regarding the activities developed with the children in the intervention stage, it is important to have in mind that there were several activities focusing on the development and improvement of language skills, as well as on the development of social skills and anxiety and aggression control.

The intervention was developed by means of activities proposed with concrete material (games and toys), shared reading and image-based reading, and activities developed through application programs used on tablets. The proposal of reading stories was adapted from the research by Aram, Fine and Ziv (2013) where the authors tested the reading of shared stories in four different reading moments: (1) exploration of the topic and story of the book; (2) exploration of socio-cognitive topics; (3) correspondence to the children's life experiences, and (4) the children retell the story read. In this survey, the four readings were transformed into three: (1) exploration of the theme and story of the book; (2) exploration of socio-cognitive themes and correspondence to children's life experiences, and (3) 
children retell the story read. The image-based reading of stories was adapted from Melo's (2011) proposal that develops the image-based reading of stories in three stages: (1) autonomous narrative to the researcher in which children observe the images and narrate what they understand about them; (2) assisted narrative in which the researcher asks the children to explain the identity of the narrative protagonists, paying attention and expressing key elements of the story to understand the reasons for some behaviors of the characters; and (3) autonomous narrative after assistance, in which the researcher asks children to narrate or tell the story, based on everything they have understood.

The intervention using games and applications was developed by the authors of the study. Some activities using concrete material were adapted from different authors (Adams, Foorman, Lundberg, \& Beeler, 2006; Almeida, 2011; Aram et al., 2013; Araújo, Lima, Pereira, Dias, \& Diniz, 2009; Mello, 2011; Nascimento, 2001; Navarro, 2008; Perez, 2011).

The games and toys used in the activities developed with concrete material were classified into games for improvement of: intrapersonal skills; interpersonal skills; perception, location, memory and auditory attention; identification of rhymes, alliterations, synthesis, segmentation and syllable manipulation and word awareness; expressive and receptive language and simple rules sung.

The decision for electronic devices called tablets was based on the aim of optimizing the use of resources, taking into consideration the wide range of programs and possibilities offered by the application programs used and the functionality offered by these devices. Bottentuit Junior (2012) lists some of the many advantages offered by these devices to perform school tasks: accessibility, easiness to carry, and can be used in different environments; textbooks can be downloaded; offer connectivity in any geographic space, content portability; allow users to download a range of applications that make the device more complete and functional; allow a text or an image to be viewed in greater detail, that is, with the opening of the fingers over any area of the screen you can see everything you want in larger size. The applications used were categorized "by function: games; interactive books by touch; characters responding or repeating the child's speech; discriminating and classifying different sounds and tasks to deal with emotions and feelings" (Varanda et al. 2015b, p. 141). Tablet activities are similar to those of concrete material as they intended to focus on improving common skills. The only exceptions are touch-based interactive books and characters that respond to the child's speech, which are only possible with the use of this type of technology. The reading of stories on interactive books used on tablets can be compared to the reading of stories with or without directed play in the case of activities with concrete material.

The activities performed with concrete material and using tablets are described in Charts 1 and 2.

Data obtained in pre and post-intervention stages in both groups were treated through descriptive and inferential statistic.

\section{RESULTS}

Of the 178 subjects assessed, 90 were female and 88 male.

To assess potential language gains, the control group was divided into high-performance control group and low-performance control group in language tests (TvAud, TvExp, LDS and ASPA) as follows: after testing with all participants, before the intervention, the individual means of the participants of the control group were calculated based on the sum of all language tests. The 47 subjects with the best averages made up the high-performance control group. The other 47 subjects with lower averages made up the lowperformance control group. Regarding the statistical analysis to verify differences between groups in language skills after intervention, three groups were used: high-performance control group (GCa), low-performance control group $(\mathrm{GCb})$ and experimental group (GE). The experimental design with three groups allows the quantification of gains in the group exposed to the intervention and observe if gains in this group could match those of the high-performance control group or be at an intermediate level between the gains of the control group below and above average (Capovilla \& Capovilla, 2000).

Descriptive statistical analyzes of the total scores were conducted in the TvAud, TvExp, ASPA and LDS tests in the high and low performance control groups and in the experimental group. Table 1 presents these results.

In order to check the statistical significance of the difference in language performance of the three groups in the post-test, we performed the Analysis of Variance of the effect of the types of group on the scores of language tests before and after the intervention. Table 2 summarizes these findings.

There was a significant difference among all groups in the post-intervention, except for the performance in the ASPA, indicating that the gains cannot be attributed to the intervention for the development of auditory processing skills.

Then, Bonferroni's multiple comparisons analysis was performed to identify significant differences between the high and low performance and experimental control groups 
Chart 1.

Description of the activities developed with applications on tablets

\begin{tabular}{|c|c|}
\hline Activity & Classification of applications (Varanda et al., 2015) \\
\hline Doodlecast ${ }^{\mathrm{a}, \mathrm{b}, \mathrm{e}}$ & Tasks to manage emotions and feelings \\
\hline Talking Larry ${ }^{b, c, e}$ & Characters answering or repeating the child's discourse \\
\hline Animal Face ${ }^{a, b, e}$ & Tasks to manage emotions and feelings \\
\hline Baby chords ${ }^{b, c}$ & Discriminating and classifying different sounds \\
\hline $\begin{array}{l}\text { Millie, um livro de história } \\
\mathrm{a}, \mathrm{b}, \mathrm{e}\end{array}$ & Tasks to manage emotions and feelings/ interactive book through touch \\
\hline Talking Tom ${ }^{\mathrm{a}, \mathrm{b}, \mathrm{c}, \mathrm{e}}$ & Characters answering or repeating the child's discourse \\
\hline Pip and Posy ${ }^{\mathrm{a}, \mathrm{b}}$ & $\begin{array}{l}\text { Tasks to manage emotions and feelings/ game with playful activities on topics in the domain of language and } \\
\text { behavior }\end{array}$ \\
\hline Checkup - Calilou ${ }^{\text {a, e }}$ & Games with playful activities on topics in the domain of language and behavior \\
\hline Galinha Pintadinha ${ }^{\text {c.e }}$ & Discriminating and classifying different sounds \\
\hline Dora aventureira ${ }^{\mathrm{b}, \mathrm{e}}$ & Tasks to manage emotions and feelings \\
\hline Quem soltou o Pum? $?^{a, b, e}$ & Interactive books through touch/ tasks to manage emotions and feelings \\
\hline ABC Palavras ${ }^{\mathrm{c}, \mathrm{d}}$ & Discriminating and classifying different sounds \\
\hline $\mathrm{ABC}$ Crianças ${ }^{\mathrm{c}, \mathrm{d}, \mathrm{e}}$ & Discriminating and classifying different sounds \\
\hline Meu Tom a, b, c, e & Tasks to manage emotions and feelings/ characters answering or repeating the child's discourse \\
\hline Os $10 \operatorname{amigos}^{\mathrm{a}, \mathrm{b}, \mathrm{e}}$ & Games with playful activities on topics in the domain of language and behavior/interactive book through touch \\
\hline Timo Kids ${ }^{\mathrm{b}, \mathrm{c}, \mathrm{e}}$ & Games with playful activities on topics in the domain of language and behavior \\
\hline
\end{tabular}

Remark. Skills developed:

a intrapersonal

$\mathrm{b}$ interpersonal

${ }^{c}$ perception, location, memory and auditory attention

${ }^{d}$ identification of rhymes, alliterations, synthesis, segmentation and handling of syllables and words awareness

${ }^{\mathrm{e}}$ expressive and receptive language.

in post-intervention language tests. Table 3 summarizes the data.

Bonferroni's post hoc analysis showed statistically significant post-intervention differences in the Language Development Questionnaire for Age 18-35 Months between the low-performance control group $(\mathrm{GCb})$ and the experimental group, indicating that the gains reported by the experimental group have even exceeded the gains of the high-performance control group, i.e., scores were above the average of the high-performance control group. There was significant difference between the low-performance control group and the experimental group in the postintervention Usp Auditory Vocabulary Test (TVAud-A33o) and Post-Expressive Vocabulary Test (TVExp-100r) ( Pos_int_TvExp), indicating, once again, that the proposed intervention is more effective when compared to the worst performing group, suggesting that the intervention could generate greater gains in populations with worse performances in auditory and expressive vocabulary. Regarding the Simplified Auditory Processing Assessment in the post-test, there was no statistical significance in the comparison between any groups, indicating that, despite some gains observed in the averages of all groups, for the experimental group they may have not resulted from the intervention made.

For the assessment of potential behavioral gains, groups were further divided to generate a high-performance control group and a low-performance control group on the $\mathrm{CBCL}$ and the experimental group. After testing performed before the intervention, the individual total scores on the CBCL test were observed. The 47 subjects with the highest scores made up the low-performance control group, since in this test the higher the score, the greater the behavioral problems. The other 47 subjects with lower scores made up the high-performance control group, since the lower the score, the better the behavioral performance. Thus, for statistical analyzes to verify differences between behavioral groups after intervention, three groups were used: control group of high-performance in behavior (GCa_comp), control group of low-performance in behavior (GCb_comp) and experimental group in behavior (GE_comp). 
Chart 2.

Description of the activities developed with concrete material

\begin{tabular}{|c|c|}
\hline Activity & Description \\
\hline I am, I can ${ }^{\text {a,b,e }}$ & The activity consists of drawing the self and making statements about personal characteristics. \\
\hline Escravos de Jó ${ }^{\mathrm{b}, \mathrm{d}, \mathrm{e}}$ & Nursery rhyme of very simple rule that demands concentration and attention using different objects. \\
\hline Statue of feelings ${ }^{\text {a }}$ & Listening to a song that, when ended, the subjects must present facial expression related to a feeling. \\
\hline Feelings memory game ${ }^{a, c}$ & Cards with facial expressions referring to different feelings are used. \\
\hline Body scheme a, b,e & $\begin{array}{l}\text { Drawing of the human body by a subject as the model, discussing personal characteristics and those common } \\
\text { with the fellows. }\end{array}$ \\
\hline Family drawing a & Drawing of the family picture of each subject, with discussion and sharing of the production with the group. \\
\hline Box of surprises ${ }^{b}$ & $\begin{array}{l}\text { Development of actions that favor skills in interpersonal relationships such as hugging the mate, for example, by } \\
\text { raffling cards with images representing those actions. }\end{array}$ \\
\hline Meaning of names ${ }^{a}$ & $\begin{array}{l}\text { Presentation of cards with the names and pictures of the children to build a panel. When the panel is exhibited, } \\
\text { the reason for the selection of each name is discussed. }\end{array}$ \\
\hline Who tells a tale adds a tail a,b,c & Narration started by the mediator, complemented by the children and, by the end, interpreted by all. \\
\hline Shared reading of stories ${ }^{a, b, e}$ & Shared reading of stories according to Aram, Fine, e Ziv (2013). \\
\hline Recognizing letters ${ }^{\mathrm{d}}$ & $\begin{array}{l}\text { Recognition of the number of letters, initial and final phoneme, the final sound, number of vowels of the } \\
\text { children's names written on cards decorated with illustrations with the same initial phoneme as the child' name. }\end{array}$ \\
\hline Image-based reading of stories ${ }^{c}$ & Image-based reading according to Mello (2011) \\
\hline Monsters factory ${ }^{\mathrm{a}, \mathrm{b}, \mathrm{e}}$ & $\begin{array}{l}\text { Use of play dough to build a monster factory. Debate about feelings and behaviors based on the features of the } \\
\text { monsters. }\end{array}$ \\
\hline Sound location $^{c}$ & Listening to different sounds that must be identified. \\
\hline $\begin{array}{l}\text { Blind man's bluff game and } \\
\text { meow cat game }\end{array}$ & Blinded children must recognize the other children's voices. \\
\hline The wand of flowers ${ }^{\mathrm{c}, \mathrm{d}}$ & $\begin{array}{l}\text { Tales told by the mediator and children add sound using different materials: music instruments, acetate plates, } \\
\text { objects in the surroundings, etc. }\end{array}$ \\
\hline Sound bingo ${ }^{\mathrm{c}}$ & $\begin{array}{l}\text { Use of cards with drawings and chips with words corresponding to the drawings whose names must start with } \\
\text { the target phoneme. }\end{array}$ \\
\hline Sound memory game ${ }^{c}$ & Uses of boxes with different materials that produce different sounds. \\
\hline $\begin{array}{l}\text { Stories with activities of } \\
\text { articulation }^{\mathrm{c}, \mathrm{d}, \mathrm{e}}\end{array}$ & $\begin{array}{l}\text { Child tales emphasizing the target phoneme that is to be repeated by the children using several materials. The } \\
\text { phoneme will be issued in isolate and then in syllables. }\end{array}$ \\
\hline
\end{tabular}

Remark. Skills developed:

a intrapersonal

$\mathrm{b}$ interpersonal

${ }^{c}$ perception, location, memory and auditory attention

d identification of rhymes, alliterations, synthesis, segmentation and handling of syllables and words awareness

e expressive and receptive language.

Descriptive statistical analyses of the CBCL total scores were performed in the high and low performance control groups and the experimental group in the pre and post-test. Following is Table 4 with the results.

The results found show great dispersion of the subjects' scores in relation to the mean of the group pre and post-test, indicating the group heterogeneity regarding behavioral manifestations.

In order to verify the statistical significance of the difference in behavior performances in post-test of the high and low-performance and experimental control groups, we performed the Analysis of Variance of the effect of the types of group on the CBCL scores after the intervention. Table 5 summarizes these findings.
All subjects in all three groups reported gains in behavioral performance as the total score on the CBCL decreased after the intervention. After the analysis of variance, a significant difference between all groups in the post-intervention against the total score in the CBCL was found, indicating that the gains can be attributed to the intervention aimed to minimize behavioral difficulties.

Then Bonferroni's analysis of multiple comparisons was performed to identify significant differences between the high and low-performance and experimental control groups in the CBCL in post-intervention. Table 6 summarizes the data.

Bonferroni's post hoc analysis showed statistically significant differences between all groups. Regarding the 
Table 1

Descriptive statistics of the language tests before and after the intervention of high and low-performance and experimental control groups

\begin{tabular}{|c|c|c|c|c|c|c|}
\hline Tests & Groups & $\mathbf{N}$ & Mean & $\begin{array}{l}\text { Standard } \\
\text { deviation }\end{array}$ & Minimum & Maximum \\
\hline \multirow[t]{4}{*}{ Pre_int_LDS ${ }^{a}$} & $\mathrm{GCb}^{\mathrm{i}}$ & 47 & 224.8 & 52.7 & 82 & 293 \\
\hline & $\mathrm{GCa}^{\mathrm{j}}$ & 47 & 288.8 & 14 & 255 & 310 \\
\hline & $\mathrm{GE}^{\mathrm{k}}$ & 84 & 267.5 & 52.5 & 76 & 310 \\
\hline & Total & 178 & 261.8 & 51.4 & 76 & 310 \\
\hline \multirow[t]{4}{*}{ Pre_int_Tv_Aud ${ }^{b}$} & $\mathrm{GCb}$ & 47 & 24.2 & 4.8 & 12 & 32 \\
\hline & $\mathrm{GCa}$ & 47 & 28 & 3.8 & 19 & 33 \\
\hline & GE & 84 & 26.6 & 4.5 & 8 & 33 \\
\hline & Total & 178 & 26.3 & 4.6 & 8 & 33 \\
\hline \multirow[t]{4}{*}{ Pre_int_Tv_Exp ${ }^{c}$} & $\mathrm{GCb}$ & 47 & 52.9 & 15.2 & 3 & 73 \\
\hline & $\mathrm{GCa}$ & 47 & 67.3 & 11 & 36 & 87 \\
\hline & GE & 84 & 61.3 & 13.7 & 21 & 88 \\
\hline & Total & 178 & 60.7 & 14.4 & 3 & 88 \\
\hline \multirow[t]{4}{*}{ Pre_int_ASPA ${ }^{\mathrm{d}}$} & $\mathrm{GCb}$ & 47 & 5.8 & 1.4 & 2 & 8 \\
\hline & $\mathrm{GCa}$ & 47 & 6.7 & 1.5 & 4 & 10 \\
\hline & GE & 84 & 6.1 & 1.8 & 3 & 11 \\
\hline & Total & 178 & 6.2 & 1.7 & 2 & 11 \\
\hline \multirow[t]{4}{*}{ Pos_int_LDS ${ }^{\mathrm{e}}$} & $\mathrm{GCb}$ & 47 & 267.5 & 43.7 & 127 & 310 \\
\hline & $\mathrm{GCa}$ & 47 & 284.6 & 33 & 165 & 310 \\
\hline & GE & 84 & 290.7 & 29.6 & 107 & 310 \\
\hline & Total & 178 & 283 & 35.8 & 107 & 310 \\
\hline \multirow[t]{4}{*}{ Pos_int_Tv_Aud ${ }^{\mathrm{f}}$} & $\mathrm{GCb}$ & 47 & 28.2 & 2.9 & 21 & 32 \\
\hline & $\mathrm{GCa}$ & 47 & 30 & 2.3 & 24 & 33 \\
\hline & GE & 84 & 30.5 & 2.2 & 24 & 33 \\
\hline & Total & 178 & 29.8 & 2.6 & 21 & 33 \\
\hline \multirow[t]{4}{*}{ Pos_int_ASPA ${ }^{g}$} & $\mathrm{GCb}$ & 47 & 7.3 & 1.6 & 5 & 11 \\
\hline & $\mathrm{GCa}$ & 47 & 7.9 & 1.8 & 4 & 10 \\
\hline & GE & 84 & 7.6 & 1.8 & 4 & 11 \\
\hline & Total & 178 & 7.6 & 1.7 & 4 & 11 \\
\hline \multirow[t]{4}{*}{ Pos_int_Tv_Exp ${ }^{\mathrm{h}}$} & $\mathrm{GCb}$ & 47 & 66.4 & 10 & 45 & 88 \\
\hline & $\mathrm{GCa}$ & 47 & 77.5 & 7.7 & 57 & 93 \\
\hline & GE & 84 & 74 & 9.2 & 46 & 89 \\
\hline & Total & 178 & 73 & 9.9 & 45 & 93 \\
\hline
\end{tabular}

Remark.

${ }^{a}$ Questionnaire of Language Development to the Age of 18 to 35 months in pre-intervention

${ }^{\mathrm{b}}$ Usp Auditory Vocabulary Test in pre-intervention

${ }^{c}$ Test of Expressive Vocabulary in pre-intervention

d Simplified Assessment of the Auditory Processing in pre-intervention

${ }^{e}$ Questionnaire of Language Development to the Age of 18 to 35 months in post-intervention

${ }^{\mathrm{f}}$ Usp Auditory Vocabulary Test in post-intervention

${ }^{g}$ Simplified Assessment of the Auditory Processing in post-intervention

${ }^{\text {h }}$ Test of Expressive Vocabulary in post-intervention

${ }^{i}$ Low-performance control group

${ }^{\mathrm{j}}$ High-performance control group

${ }^{\mathrm{k}}$ Experimental group 
Table 2

Results of the ANOVA having type of group as factor and total performances in language tests as dependent variables, including $F, p$

\begin{tabular}{lcc}
\hline Test & $\boldsymbol{F}$ & $\boldsymbol{p}$ \\
\hline Pos_int_LDS & $0.001^{* *}$ \\
Pos_int_Tv_Aud & 6.8 & $0.000^{* *}$ \\
Pos_int_ASPA & 13.7 & 0.297 \\
Pos_int_Tv_Exp & 1.2 & $0.000^{* *}$ \\
\hline
\end{tabular}

Remark. * $\mathrm{p}<.05 ; * \mathrm{p}<.01$

${ }^{a}$ Questionnaire of Language Development to the Age of 18 to 35 months in post-intervention

${ }^{\mathrm{b}}$ Usp Auditory Vocabulary Test in post-intervention

c Simplified Assessment of the Auditory Processing in post-intervention

${ }^{\mathrm{d}}$ Test of Expressive Vocabulary in post-intervention

Table 3

Results of the Bonferroni's analysis of multiple comparisons among the performance of the three groups

\begin{tabular}{|c|c|c|c|c|}
\hline Tests & group & group & Standard error & $p$ \\
\hline \multirow[t]{6}{*}{ Pos_int_LDS ${ }^{a}$} & $\mathrm{GCb}^{\mathrm{e}}$ & $\mathrm{GCa}$ & 7.2 & $0.055^{*}$ \\
\hline & & GE & 6.3 & $0.001^{* *}$ \\
\hline & $\mathrm{GCa}^{\mathrm{f}}$ & $\mathrm{GCb}$ & 7.2 & $0.055^{*}$ \\
\hline & & GE & 6.3 & 0.988 \\
\hline & $\mathrm{GE}^{\mathrm{g}}$ & $\mathrm{GCb}$ & 6.3 & $0.001^{* *}$ \\
\hline & & $\mathrm{GCa}$ & 6.3 & 0.988 \\
\hline \multirow[t]{6}{*}{ Pos_int_Tv_Aud ${ }^{\mathrm{b}}$} & $\mathrm{GCb}$ & $\mathrm{GCa}$ & 0.5 & $0.002^{*}$ \\
\hline & & GE & 0.4 & $0.000^{* *}$ \\
\hline & $\mathrm{GCa}$ & $\mathrm{GCb}$ & 0.5 & $0.002^{*}$ \\
\hline & & GE & 0.4 & 0.607 \\
\hline & GE & $\mathrm{GCb}$ & 0.4 & $0.000^{* *}$ \\
\hline & & $\mathrm{GCa}$ & 0.4 & 0.607 \\
\hline \multirow[t]{6}{*}{ Pos_int_ASPA ${ }^{c}$} & $\mathrm{GCb}$ & $\mathrm{GCa}$ & 0.4 & 0.364 \\
\hline & & $\mathrm{GE}$ & 0.3 & 0.965 \\
\hline & $\mathrm{GCa}$ & $\mathrm{GCb}$ & 0.4 & 0.364 \\
\hline & & GE & 0.3 & 1.000 \\
\hline & GE & $\mathrm{GCb}$ & 0.3 & 0.965 \\
\hline & & $\mathrm{GCa}$ & 0.3 & 1.000 \\
\hline \multirow[t]{6}{*}{ Pos_int_Tv_Exp ${ }^{\mathrm{d}}$} & $\mathrm{GCb}$ & $\mathrm{GCa}$ & 1.9 & $0.000^{* *}$ \\
\hline & & GE & 1.7 & $0.000^{* *}$ \\
\hline & $\mathrm{GCa}$ & $\mathrm{GCb}$ & 1.9 & $0.000^{* *}$ \\
\hline & & GE & 1.7 & 0.102 \\
\hline & GE & $\mathrm{GCb}$ & 1.7 & $0.000^{* *}$ \\
\hline & & $\mathrm{GCa}$ & 1.7 & 0.102 \\
\hline
\end{tabular}

Remark. $* \mathrm{p}<.05 ; * * \mathrm{p}<.01$

${ }^{\text {a }}$ Questionnaire of Language Development to the Age of 18 to 35 months in post-intervention

${ }^{\mathrm{b}}$ Usp Auditory Vocabulary Test in post-intervention

c Simplified Assessment of the Auditory Processing in post-intervention

${ }^{d}$ Test of Expressive Vocabulary in post-intervention

${ }^{\mathrm{e}}$ Low-performance control group

${ }^{\mathrm{f}}$ High-performance control group

${ }^{\mathrm{g}}$ Experimental group 
Table 4

Descriptive analysis of the CBCL total scores in all the three groups before and after the intervention

\begin{tabular}{|c|c|c|c|c|c|c|}
\hline Test & Groups & $\mathbf{N}$ & Mean & $\begin{array}{l}\text { Standard } \\
\text { deviation }\end{array}$ & Minimum & Maximum \\
\hline \multirow[t]{4}{*}{ Pre_int_CBCL ${ }^{a}$} & $\mathrm{GCb}_{-}$comp ${ }^{\mathrm{c}}$ & 47 & 62.4 & 13 & 48 & 99 \\
\hline & $\mathrm{GCa}_{-}$comp $^{\mathrm{d}}$ & 47 & 31.2 & 10.4 & 13 & 47 \\
\hline & GE_comp ${ }^{e}$ & 84 & 51.5 & 21.5 & 8 & 109 \\
\hline & Total & 178 & 49 & 20.6 & 8 & 109 \\
\hline \multirow[t]{4}{*}{ Pos_int_CBCL ${ }^{b}$} & GCb_comp & 47 & 53.4 & 17.7 & 23 & 91 \\
\hline & GCa_comp & 47 & 29.5 & 16 & 4 & 76 \\
\hline & GE_comp & 84 & 41.1 & 17.9 & 9 & 92 \\
\hline & Total & 178 & 41.3 & 19.4 & 4 & 92 \\
\hline
\end{tabular}

Nota.

${ }^{a}$ Child Behavior Checklist in pre-intervention

${ }^{\mathrm{b}}$ Child Behavior Checklist in post-intervention

${ }^{\mathrm{c}}$ Low-performance control group in the $C B C L$

${ }^{\mathrm{d}}$ High-performance control group in the $C B C L$

experimental group in the $C B C L$

Table 5

Results of the ANOVA having type of group as factor and total performances in the CBCL as dependent variables, including $F, p$

\begin{tabular}{lcc}
\hline Teste & $\boldsymbol{F}$ & $\boldsymbol{p}$ \\
\hline Pos_int_CBCL & & \\
\hline
\end{tabular}

Nota. $* \mathrm{p}<.05 ; * * \mathrm{p}<.01$

${ }^{a}$ Child Behavior Checklist in post-intervention.

Table 6

Results of Bonferroni's analysis of multiple comparisons among the performances of the three groups in behavior

\begin{tabular}{|c|c|c|c|c|}
\hline Test & group & Group & Standard error & $p$ \\
\hline \multirow[t]{6}{*}{ Pos_int_CBCL ${ }^{a}$} & GCb_comp ${ }^{\mathrm{b}}$ & GCa_comp & 3.6 & $0.000^{* *}$ \\
\hline & & GE_comp & 3.2 & $0.000^{* *}$ \\
\hline & GCa_comp ${ }^{c}$ & GCb_comp & 3.6 & $0.000^{* *}$ \\
\hline & & GE_comp & 3.2 & $0.001^{* *}$ \\
\hline & GE_comp ${ }^{\mathrm{d}}$ & GCb_comp & 3.2 & $0.000^{* *}$ \\
\hline & & GCa_comp & 3.2 & $0.001^{* *}$ \\
\hline
\end{tabular}

Nota. $* \mathrm{p}<.05 ; * * \mathrm{p}<.01$

${ }^{a}$ Child Behavior Checklist in post-intervention

${ }^{\mathrm{b}}$ Low-performance control group in the $C B C L$

${ }^{c}$ High-performance control group in the $C B C L$

${ }^{\mathrm{d}}$ Experimental group in the $C B C L$.

post-intervention, the experimental group, when compared to the control groups, showed statistically significant difference suggesting the effects of the intervention on the experimental group.

\section{DISCUSSION}

In general, the results found indicate that children in kindergarten, who present some difficulties in language development as well as in behaviors, improve in the areas approached, mainly when submitted to the intervention for improvement and development of these skills.

Of the survey subjects, $50.6 \%$ are female and $49.4 \%$ male. Although the equitable distribution of gender was 
not a methodological criterion, the percentages found in the study group depict the demographic reality of the kindergarten students of the Santos Municipal Schools Network that in 2015 had 3768 boys (50.1\%) and 3748 girls (49.9\%), supporting the gender representation of this group.

The parents' responses in the Language Development Questionnaire for Age 18-35 Months showed gains in post-intervention in the experimental and low-performance control groups. This result seems to indicate that children with greater difficulties benefit from schooling (low-performance control group) and even more from interventions that focus on vocabulary improvement and expansion. This also occurred in relation to auditory and receptive vocabulary, through the test answered by the children. In this case, however, there was gain in all groups after the intervention. These results show, on one hand, that results for the instruments completed by parents and children had similar results; on the other hand, instruments completed by children showed greater sensitivity to detect the post-intervention change, since the high-performance control group also reported post-test gains.

Regarding the behaviors assessed, all groups scored lower (fewer behavioral problems) in the post-test, especially in the experimental and low-performance control groups. This suggests that, also in this case, children with greatest difficulties are those that benefit most from specific interventions to improve adaptive behavioral repertoire.

It is worth emphasizing that the interventions made focused on all students in the classrooms involved in the survey, in a preventive and interventional way. This prevention model, according to Powell, Dunlap, and Fox (2006), involves broader yet more specialized services and strategies, focusing on young children at risk for behavioral and other problems. Thus, this model could be suitable to the school environment, since it does not propose actions by professionals in the areas of speech therapy and psychology with a clinical focus. In addition, it supports the role and function of professionals who can act at institutional level in a preventive and interventional manner, based on guidance to teachers and professionals directly involved in the teaching and learning processes.

Based on the finding that the intervention proved to be more effective in low-performance experimental groups and considering that $76 \%$ of families are in categories 1 to 5 of Hollingshead's (2011) occupational scale, we conclude that this intervention proposal can benefit children in socioeconomic disadvantage. On the one hand, vocabulary teaching and the systematic provision of language stimulation situations in the school environment favors the development and refinement of skills that can prepare children to start writing. On the other hand, the opportunity to discuss and learn about different ways of speaking and dealing with feelings may also prevent further social and behavioral difficulties.

Similarly, the specific knowledge of professionals in the field of psychology and language justifies, among teachers, the suggestion of systematically including activities that prioritize the refinement of these skills, and could suggest the use of everyday situations to that purpose, as proposed by Whorrall and Cabell (2016).

However, there were only three to four meetings with parents scheduled by the school board, and not all parents attended those meetings. Systematic education to parents about the best ways to promote interactive situations that could benefit language development and pro-social behavioral repertoire did not happen with the consistency planned by the researchers mainly because of the parents' alleged lack of availability and time.

\section{FINAL REMARKS}

Having in mind a preventive and interventional model for problems related to language development and adaptive behavior repertoire, both language and behavioral difficulties should be detected early, in order to flag potential problems in the acquisition of academic and social skills in children at preschool age. Therefore, children need to be assessed in their early years to prevent difficulties resulting from such deficits.

This preventive and interventional model can support teachers and parents to minimize and solve problems at early stage, being an efficient strategy to meet the needs of childcare in the family and institutionalized environment, significantly reducing the costs with later intervention processes and the resulting problems (such as literacy difficulties, attention problems, bullying) and their consequences (such as social mismatch, school underperformance).

These results lead to the conclusion that an intervention model, in which professionals in the field of speech therapy and psychology instruct the kindergarten teachers on the use of activities to the successful development of language and to the construction of appropriate behavioral repertoire, could significantly contribute to the improvement of performance and adaptation in these skills for children of 3 to 4 years old.

However, some children remain feeling difficulties or worsen their performance. Thus, after the intervention, it is easier to identify and select more accurately the children who are likely to need specialized attention or referral to health 
professionals. This is yet another possibility for optimizing the use of health and education resources.

One of the most relevant limitations of this study was the fact that parents were not as active as envisaged in the intervention proposal. Further research should suggest more strategies more suitable to the inclusion and active participation of parents, not only in terms of their knowledge about their children's language and socio-emotional skills development, but also in relation to habits and strategies they could develop at home to that purpose.

\section{REFERENCES}

Achenbach, T. M., \& Rescorla, L. A. (2000). Manual for the ASEBA Preschool Forms \& Profiles. Burlington, VT: University of Vermont, Research Center for Children, Youth, \& Families.

Adams, M. J., Foorman, B. R., Lundberg, I., \& Beeler, T. (2006). Consciência fonológica em crianças pequenas. Porto Alegre: Artmed.

Almeida, A. (2011, fevereiro 17). Re: Atendimento Educacional Especializado (AEE): Terapia de processamento auditivo [Blog]. Recuperado de https://inclusaoaee.wordpress. com/2011/02/17/terapia-de-processamento-auditivo/

Aram, D., Fine Y., \& Ziv, M. (2013). Enhancing parent-child shared book reading interactions: promoting references to the book's plot and socio-cognitive themes. Early Childhood Research Quarterly, 28, 111-122. doi: 10.1016/j.ecresq.2012.03.005

Araújo, L. G. A. N., Lima, L. R., Pereira, M. R. A., Dias, F. R. N., \& Diniz, G. C. A. (2009). Tesouro dos sentimentos [online]. Recuperado de http://portaldoprofessor.mec.gov.br/ fichaTecnicaAula.html?aula=8116.

Arnold, D. H. (1997). Co-occurrence of externalizing behavior problems and emergent academic difficulties in young high-risk boys: A preliminary evaluation of patterns and mechanisms. Journal of Applied Developmental Psychology, 18, 317-330. http://dx.doi.org/ 10.1016/S0193-3973(97)80003-2

American Speech-Language-Hearing Association. (1996). Task force on central auditory processing consensus development: Central auditory current status of research and implications for clinical practice. Journal of the American Academy of Audiology, 5, 41-54. http://dx.doi.org/10.1044/10590889.0502.41

Bordin, I. A. S., Mari, J. J., \& Caeiro, M. F. (1995). Validação da versão brasileira do "Child Behavior Checklist" (CBCL) Inventário de Comportamentos da Infância e da Adolescência: Dados preliminares. Revista Brasileira de Psiquiatria, 17(2), 55-56.

Bornstein, M. H., Hahn, C. S., \& Suwalsky, J. T. D. (2013). Language and internalizing and externalizing behavioral adjustment: Developmental pathways from childhood to adolescence. Development and Psychopathology, 25(3), 857878. http://dx.doi.org/ 10.1017/S0954579413000217.

Bottentuit Junior, B. J. (2012). Do computador ao tablet: Vantagens pedagógicas na utilização de dispositivos móveis na educação. Revista EducaOnline, 6(1), 125-149. Recuperado de http:// www.latec.ufrj.br/revistas/index.php?journal=educaonline\&p age $=$ article \&op $=$ view \& path $\% 5 \mathrm{~B} \% 5 \mathrm{D}=291 \&$ path $\% 5 \mathrm{~B} \%$ $5 \mathrm{D}=416$

Capovilla, F. C., \& Capovilla, A. G. S. (2000). Problemas de leitura e escrita: Como identificar, prevenir e remediar numa abordagem fônica. São Paulo: Memnon.

Capovilla, F. C., Negrão, V. B., \& Damázio, M. (2011). Teste de vocabulário auditivo e teste de vocabulário expressivo: Validado e normatizado para o desenvolvimento da compreensão e da produção da fala dos 18 meses aos 6 anos. São Paulo: Memnon.

Capovilla, F. C., \& Salido, L. F. M. (2011). Avaliando a Aspa (Avaliação Simplificada do Processamento Auditivo): Efeito de série escolar e de inteligência não verbal sobre localização de fonte sonora e memória sequencial de sons verbais e não verbais. In F. C. Capovilla. (Org.), Transtornos de aprendizagem: Progressos em avaliação e intervenção preventiva e remediativa (pp. 141-157). São Paulo, SP: Memnon.

D’Abreu, L. C. F., \& Marturano, E. M. (2010). Associação entre comportamentos externalizantes e baixo desempenho escolar: Uma revisão de estudos prospectivos e longitudinais. Estudos de Psicologia, Natal, 15(1), 43-45.

Duarte, C. S., \& Bordin, I. A. S. (2000). Instrumentos de avaliação. Revista Brasileira de Psiquiatria, 22, 55-58. http://dx.doi. org/10.1590/S1516-44462000000600015.

Hancock, T. B., Kaiser, A. P., Delaney, E. M. (2002). Teaching parents of preschoolers at high risk: strategies to support language and positive behavior. Topics in Early Childhood Special Education, 22 (4), 191-212. http://dx.doi. org/10.1177/027112140202200402

Hollingshead, A. B. (2011). Four factor index of social status. Yale Journal of Sociology, 8, 21-51.

McClelland, M. M., Cameron, C. E., Connor, C. M., Farris, C. L., \& Jewkes, A. M., \& Morrison, F. J. (2007). Links between behavioral regulation and preschoolers' literacy, vocabulary, and math Skills. Developmental Psychology, 43 (4), 947-959. http://dx.doi.org/ 10.1037/0012-1649.43.4.947

Melo, L. E. (2011). Cognição e linguagem: Perspectivas interdisciplinares. Curitiba: Editora CRV. doi: 10.24824/978858042037.1

Moura, C. B., Marinho-Casanova, M. L, Meurer, P. H., \& Campana C. (2008). Caracterização da clientela pré-escolar de uma clínica-escola brasileira a partir do Child Behavior Checklist (CBCL). Contextos Clínicos, 1(1), 1-8. Recuperado de http:// pepsic.bvsalud.org/scielo.php?script=sci_arttext\&pid=S1983 $34822008000100001 \& \operatorname{lng}=\mathrm{pt} \& \operatorname{tlng}=\mathrm{pt}$

Nascimento, L. C. R. (2001). Brincando com os sons: Jogos para a terapia de distúrbios articulatórios. Carapicuíba, SP: PróFono.

Navarro. A. A. (2008). Estimulação precoce: Inteligência emocional e cognitiva. São Paulo: Grupo Cultural.

Pereira, L. D., \& Schochat, E. (1997). Processamento auditivo central: Manual de avaliação. São Paulo: Editora Lovise.

Perez, V. (2011). Crescendo cantando (1 $1^{\mathrm{a}}$ ed.). São Paulo: Editora Aliança. Recuperado de http://editoraalianca.com.br/wpcontent/uploads/2015/04/Livro-Crescendo-e-Cantando.pdf.

Powell D., Dunlap G., \& Fox L. (2006). Prevention and intervention for the challenging behaviors of toddlers and preschoolers. Infants and Young Children, 19(1), 25-35. http://dx.doi.org/ 10.1097/00001163-200601000-00004

Rescorla, L., \& Alley, A. (2001). Validation of the Language Development Survey (LDS): A parent report tool for identifying language delay in toddlers. Journal of Speech, Language \& Hearing Research, 44(2), 434-445. http://dx.doi. org/ 10.1044/1092-4388(2001/035)

Silvares, E. F. M., Rocha, M. M., \& Linhares, M. B. M. (2010). Inventário de Comportamentos de Crianças entre 1 1/2 - 5 anos $(C B C L / 11 / 2-5)$. Versão brasileira do "Child Behavior Checklist for ages $11 \frac{1}{2}-5$ (Manuscrito não publicado).

Timmermans, M., van Lier, P. A. C., \& Koot, H. M. (2009). Pathways of behavior problems from childhood to late adolescence 
leading to delinquency and academic underachievement. Journal of Clinical Child \& Adolescent Psychology, 38(5), 630-638. http://dx.doi.org/ 10.1080/15374410903103502

Toscano, R. D. G. P., \& Anastasio, A. R. T. (2008). Habilidades auditivas de detecção, localização e memória em crianças de 4 a 6 anos de idade [Resumo]. Anais do $16^{\circ}$ Congresso Brasileiro de Fonoaudiologia (pp. 1-5). Trabalho apresentado no Congresso Brasileiro de Fonoaudiologia, 16. Campos do Jordão, SP.

Vallotton, C., \& Ayoub, C. (2011). Use your words: The role of language in the development of toddlers' self-regulation. Early Childhood Research Quarterly, 26(2), 169-181. http://dx.doi. org/ 10.1016/j.ecresq.2010.09.002

Varanda, C. A., Mendes, E. C. C. S., Campina, N. N., Aulicino, M. G. G. M. C., Nascimento, R. C. G. V. O., Marczak, C. M. F., ... Fernandes, F. D. M. (2015a). The Relation of externalizing behavior and central auditory processing deficits in 4-year-old children. Psychology, 6 (13), 1589-1593. http://dx.doi.org/ 10.4236/psych.2015.613156

Varanda, C. A., Mendes, E. C. C. S., Campina, N. N., Aulicino, M. G. G. M. C., Nascimento, R. C. G. V. O., Marczak, C. M. F., ... Fernandes, F. D. M. (2015b). Aplicativos para tablets sensíveis ao toque para melhorar vocabulário, processamento auditivo central e habilidades de interação social entre pré-escolares. Psicopedagogia, 32(98), 136-149. Recuperado de http://pepsic. bvsalud.org/scielo.php?script $=$ sci arttext\&pid $=\mathrm{S} 0103848620$ $15000200004 \& \operatorname{lng}=$ pt\&tlng $=$ pt.

Wright, T. S., \& Neuman, S. B. (2014). Paucity and disparity in kindergarten oral vocabulary instruction. Journal of Literacy Research, 46(3), 330-357. doi: 10.1177/1086296X14551474

Whorrall, J., \& Cabell, S. Q. (2016). Supporting children's oral language development in the preschool classroom. Early Childhood Education Journal, 44, 335-341. doi: 10.1007/ s10643-015-0719-0 